\title{
$\mathrm{BFT}$ 양식장 배출수를 활용한 도시농업용 비료개발
}

\author{
김용현 $A^{1} \cdot$ 손상규 $^{2} \cdot$ 이영식 $^{2} \cdot$ 최혜승 $^{2} \cdot$ 허무룡 $^{1,3 *}$ \\ ${ }^{1}$ 경상대학교 원예학과, ${ }^{2}$ 국립수산과학원 내수면양식연구센터, ${ }^{3}$ 경상대학교 농업생명과학연구원
}

\section{Development of Urban Agricultural Fertilizer of Effluent Water from BFT Inland Aquaculture}

\author{
Yong Hyun Kim', Sang Gyu Sohn', Young Sik Lee ${ }^{2}$, Hye Sung $\mathrm{Choi}^{2}$, and Moo Ryong Huh ${ }^{1,3 *}$ \\ ${ }^{1}$ Department of Horticulture, Gyeongsang National University, Jinju 52828, South Korea \\ ${ }^{2}$ National Institue of Fisheries Science, Inland Aquaculture Research Center, Jinhae 51691, South Korea \\ ${ }^{3}$ Institute of Agriculture \& Life Science, Gyeongsang National University, Jinju 52828, South Korea
}

\begin{abstract}
The objective of this study is to find a useful method of utilizing effluent water from the BFT inland water culture. Recently Sludge and effluent water have been noted to cause water pollution. Therefore, this progressive study of recycling method will replace the use of chemical fertilization. Effluent water from inland water culture contains many fertilization ingredients. This study used different using methods of fertilization. As a result, effluent water that isn't matured and diluted had positive effects on the growth of lettuce. Effluent water of undiluted involved many mineral elements and proper $\mathrm{pH}$ concentration for plants growth but which are involved many concentrations of $\mathrm{Na}^{+}$ion. High concentrations of $\mathrm{Na}^{+}$ions are harmful for the growth of plants. This experiment did not show plants adversely affected by $\mathrm{Na}^{+}$ions. Potentially $\mathrm{Na}^{+}$ions can cause physiological disturbances of the plant. Effluent water smells because effluent waters using is need to additional pre-treatment for removal its high concentration $\mathrm{Na}^{+}$ions and bad smell.
\end{abstract}

Key words: ingredients of fertilization, mineral elements, recycling, replace to chemical fertilization, water pollution

\section{I . 서론}

우리나라의 내수면 면적은 203,000ha으로 이를 기반으로 한 내수면 양식 기술은 1929년 현재 국립수산진흥원 진해내수면 연 구소 설립 이후 기술 개발을 통해 전국 농촌에 분양되기 시작하였 다. 현재 내수면 양식은 양식의 형태에 따라 정수식 못양식, 유수식 양식, 가두리 양식, 순환여과식 양식 등으로 구분되며, 이 중 국내 순환여과 양식은 최근 계속적인 시설 및 관리 기술의 연구, 발전으 로 미래 산업으로 급속한 발전을 보이고 있다. 특히 순환여과 양식 의 가장 기본적인 내용은 효과적인 수처리 문제로 오-폐수 처리장 및 정수처리장에서 수처리를 위하여 개발된 공법을 양어장의 특색

Received on July 7, 2016. Revised on July 12, 2016.

Accepted on July 26, 2016.

*Comesponding author:mrhuh@gnu.ac.kr

이 논문은 2016년도 국립수산과학원 수산과학연구사업인 어류 바이오 플락 양식기술(BFT) 개발(R2016019) 사업비의 지원으로 수행된 연구 입니다.
에 맞게 도입해 양어장 수처리를 위해서 어류의 배설물 및 잔이 사료를 효율적으로 처리하는 방법이다(Ryu et al., 1993). 특히 Biofloc Technology(BFT) 양식 기법은 순환여과식 양식 방법 중 최근 새로 도입된 기법으로 바이오플락(biofloc)을 기반으로 양어 장의 수처리를 위한 어류의 배설물과 잔이 사료의 제거에 바이오플 락으로 질소를 제거하는 순환여과식 양식이다(Buckling et al., 1993).

양식 산업은 어류를 고밀도의 양이 생산하기 때문에 이러한 대 량 생산에 다른 어류에서 발생한 배설물이나 사료 찌꺼기 등의 집 약적인 배출은 환경오염원으로 수질오염의 원인으로 인식되고 있 다(Subramaniam et al., 1994). 이러한 양식장의 배출수에 대한 부정적인 인식으로 인해 양식장 배출수에 대한 규제가 확대되어 배출 기준이 앞으로는 대상수계에 유입되는 오염물질을 총량으로 규제하는 수질총량규제로 전환 될 것으로 전망된다(Cho et al., 1995).

한편, Seo et al.(1997)에 따르면 양식장 물고기 배설물 중에는 질소와 인이 풍부하고 탄소와 질소의 비율인 $\mathrm{C} / \mathrm{N}$ 율이 약 10 이라는 
결과가 나왔으며 이는 물고기 배설물을 그대로 퇴비로 사용하여도 무방할 정도라고 하였다.

오래전부터 동물의 배설물을 이용한 작물의 재배는 이루어지고 있었으며, 최근에는 환경오염원으로 가축분뇨의 배출규제에 따라 가축분뇨의 농업적 재이용 방안을 모색하고자 가축분뇨의 이용한 많은 작물들의 재배 연구를 하고 있는 실정이다(Jo et al., 2001; Kang et al., 2011; Kim et al., 2011; Kim et al., 2001; Park et al., 2001; Ryoo, 2011; Shin et al., 2013).

그러므로 본 실험에서는 수질오염의 원인으로 인식되고 있는 양 식장의 배출수를 이용하여 이를 분석하고 식물의 재배에 비료로써 의 가능성 여부를 규명하고 이용하기 위한 적정 이용방안과 농도를 찾아보고자 하였다.

\section{II. 연구방법}

\section{1. 실험재료}

본 연구는 2015년 4월부터 7월까지 경상대학교 부속농장 실 험 온실에서 ‘선홍적축면' 상추(Lactuca sativa L. 'Seonhong Jeokchukmyeon', Asia Seed Co., Ltd., Korea)를 이용하여 재배 실험을 실시하였다. 2015년 4월 18일 50구 육묘용 플러그 트레이 $(60 \mathrm{~cm} \times 41 \mathrm{~cm} \times 5 \mathrm{~cm})$ 에 파종하여 발아시킨 후 2015년 5월 26일 에 $10 \mathrm{~cm}$ 이색포트에 無肥토실이(신안그로)를 배양토로 사용하 여 정식하였다. 이후 6주간 매주 1회씩 관행 액비(Hyponex high grade, Hyponex inc., Japan)와 배출수를 농도별로 희석하여 $50 \mathrm{ml}$ 씩 토양 관주하였으며, 실험구의 배치는 완전임의배치법을 실시하였다.

실험에 사용된 양식장 배출수는 경상남도 창원시 진해구 여좌 동에 위치한 국립수산과학원 내수면 양식 연구센터 BFT(Biofloc technology)양식연구장에서 받아온 것을 이용하여 실험을 진행하 였다. 배출수의 적정 이용방법과 농도를 알아보고자 다음과 같이 차이를 두었는데, 우선 배출수의 적정 이용방법을 다음과 같이 나 누었다. 먼저 숙성배출수(Matured effluent water: $\mathrm{ME}$ )는 배출수 를 양식장에서 가져와 일정기간 온실 내부 햇빛이 들지 않는 상온 의 장소에서 2 달간 저장 시킨 이후 이용하는 방법이고 신선배출수 (Fresh effluent water: FE)는 배출수를 가져와 바로 이용하는 방 법으로 배출수의 저장숙성 여부를 달리 하였다. 배출수의 적정 이 용 농도를 알아보기 위해서는 숙성배출수와 신선배출수를 각각 원 액으로 이용하는 방법(100), 1/2배(50), 1/4배(25), 1/10배(10)로 희석하여 사용하는 방법으로 희석 배율에 따라 이용방법을 달리하 였다.

\section{2. 생육조사}

상추의 생육은 2015년 7월 10일에 초장, 최대근장, 엽장, 엽폭, 엽수, 엽록소 함량(SPAD502, Minolta, Japan), 경경, 지상부와 지하부의 생체중과 건물중을 조사하였다. 엽장과 엽폭은 최하단에 서 3 번째의 잎을 선정하여 엽장과 엽폭을 측정하였으며, 경경은 뿌 리가 나기 바로 위의 지점을 디지털 버니어캘리퍼스(Absolute Dig imatic 500-182, MItutoyo Co., Japan)를 이용하여 측정하였다.

\section{3. 배출수 분석}

처리한 배출수는 매주 처리전 $1 \mathrm{~L}$ 씩 취하여 경상남도 진주시 소 재의 경남농업기술원에 성분 분석을 요청하였다.

배출수의 $\mathrm{pH}$ 와 $\mathrm{EC}$ 측정은 $\mathrm{pH} / \mathrm{EC} \mathrm{Meter(Consort} \mathrm{C830)를}$ 사용하여 측정하였다. 양액 속의 무기태 질소인 $\mathrm{NH}_{4}-\mathrm{N}$ 와 $\mathrm{NO}_{3}-\mathrm{N}$ 의 함량은 킬달분석법을 이용하였고, T-P는 아스코르빈산 환원법 을 이용하였으며, $\mathrm{Cl}$ 은 $\mathrm{AgNO}_{3}$ 적정법, $\mathrm{SO}_{4}{ }^{+}$은 $\mathrm{CNS}$ Analyzer (Vario-max, Elementar, German)를 이용하여 분석하였고, $\mathrm{HCO}_{3}^{-}$ 는 이온적정법을 통하여 분석하였으며 나머지 양이온들의 함량은 $\mathrm{ICP}$ 분석을 통하여 측정하였다.

\section{4. 통계분석}

실험 후 모든 자료의 통계분석은 통계 프로그램인 SAS(Statistical Analysis System, V. 9.2, Cary, NC, USA) 프로그램을 이용하여 Duncan 다중검정을 통해 유의성을 검정하였다.

\section{III. 결과 및 고찰}

\section{1. 배출수 성분분석}

\section{1 배출수의 $\mathrm{pH}$}

배출수를 상온 저장을 통해 숙성시켜 사용할 경우(Matured effluent water: $\mathrm{ME}$ ) 초기에는 $\mathrm{pH}$ 가 8.56 9.28의 범위로 매우 높 은 $\mathrm{pH}$ 값을 나타내다가 시간이 경과함에 따라 $\mathrm{pH}$ 값이 떨어졌으나, 전반적으로 $\mathrm{pH}$ 수치가 높은 것을 알 수 있었다. 이와 반대로 배출수 를 채취하여 바로 이용할 경우(Fresh effluent water: FE)에는 이 용 초기 $\mathrm{pH}$ 가 6.69 7.43의 범위였고, 5주차 최종 조사에서는 $\mathrm{pH}$ 값이 7.51 7.68의 범위를 보였으며 처리 전체적인 기간 동안 식물 의 생육에 적합한 범위의 값을 가지고 있었다(Fig. 1).

\section{2 배출수의 $\mathrm{EC}$}

5 주간 배출수를 작물에 처리하기 전에 수집하여 분석을 실시한 결과에 대하여 우선 같은 농도로 희석된 배출수 처리끼리 비교하여 


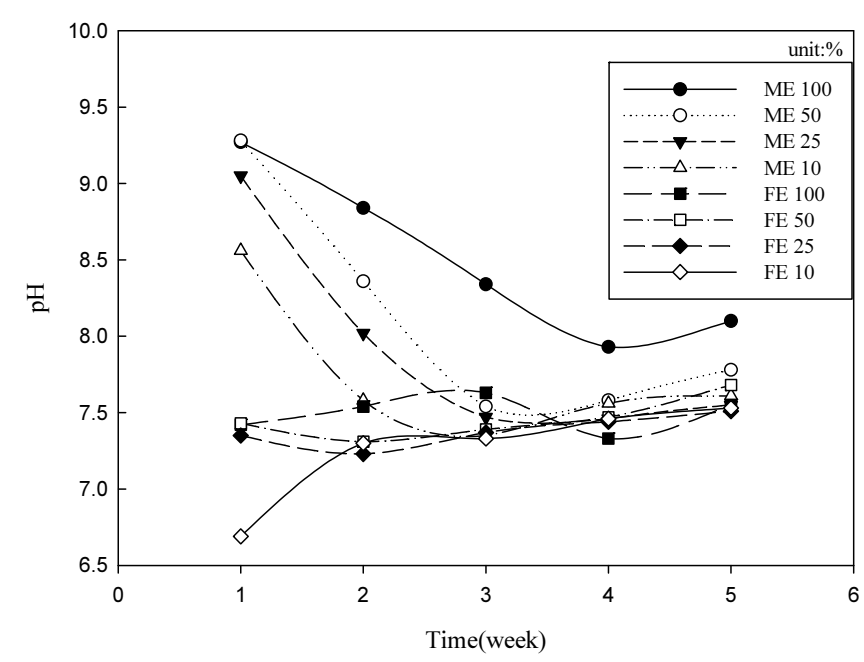

Fig. 1. Changes of $\mathrm{pH}$ of effluent water during the treatment time. $\mathrm{FE}$, Fresh effluent water; ME, Matured effluent water. 100 , Effluent water; 50 , half strength of effluent water; 25 , quarter strength of Effluent water; 10, tenth strength of Effluent water.

보면 배출수를 상온 저장하여 숙성시킨 처리(Matured effluent water: $\mathrm{ME}$ )가 대체적으로 배출수를 바로 이용한 처리(Fresh effluent water: FE)보다 낮은 EC 수치를 나타내는 것을 알 수 있 었다. 그리고 5주간 이용과정에서 FE100 처리구 이외에는 처리 경 과에 따른 $\mathrm{EC}$ 수치의 변화는 크게 없었다.

\section{3 배출수 내의 무기원소 함량}

\subsection{1 배출수 내 질소 함량}

식물의 생장에 가장 많은 양을 필요로 하는 질소의 경우 그 이용

(A)

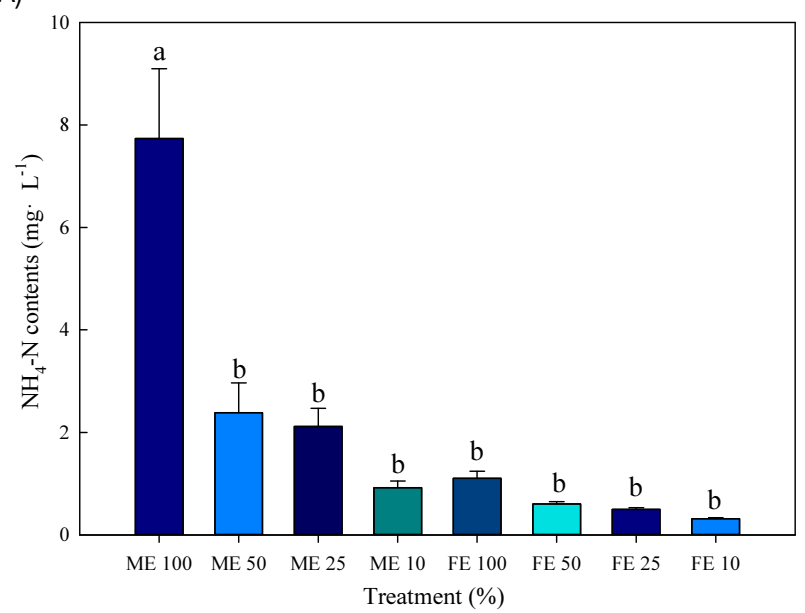

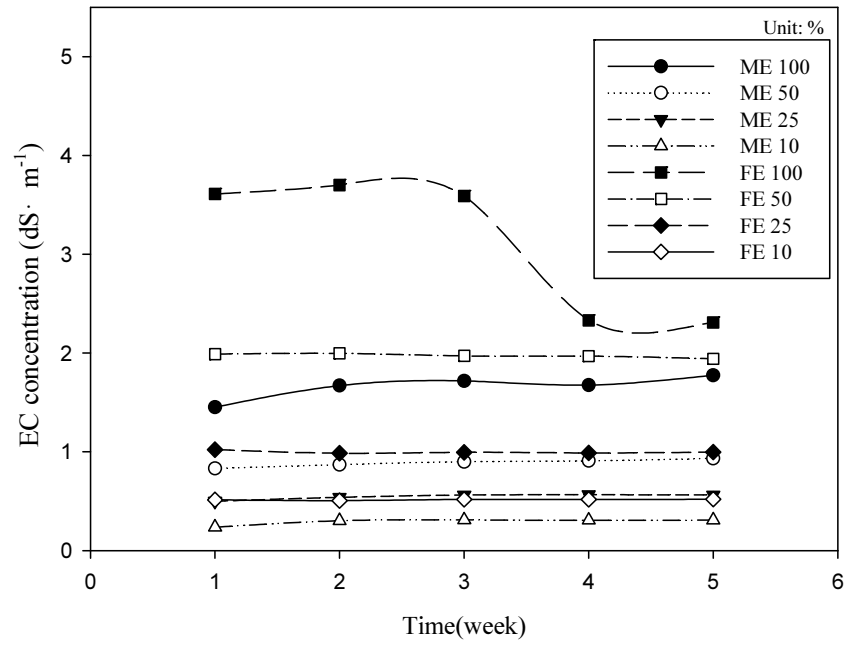

Fig. 2. Changes of $E C$ of effluent water during the treatment time. $\mathrm{FE}$, Fresh effluent water; ME, Matured effluent water. 100 , Effluent water; 50 , half strength of effluent water; 25 , quarter strength of Effluent water; 10, tenth strength of Effluent water.

형태에 따라 암모니아태 질소 $\left(\mathrm{NH}_{4}-\mathrm{N}\right)$ 와 질산태 질소 $\left(\mathrm{NO}_{3}-\mathrm{N}\right)$ 로 나뉠 수 있으며 화학적 형태가 다른 이러한 질소는 흡수성이나 체 내의 생리작용 면에서 차이가 있고 식물의 종류에 따라서도 선호성 면에서 다소간 구분되어 있다고 한다(Lim, 2006).

본 실험에서 질소의 함량은 질산태 질소의 함량이 월등히 높았 다. 각각의 질소 형태에 따른 함량의 차이를 보면 암모니아태 질소 의 경우 상온 저장을 통해 숙성 시킨 배출수(Matured effluent water: ME)처리에서 배출수를 바로 이용한 처리(Fresh effluent water: FE)보다 높았는데, 이는 배출수 내의 미생물의 대사과정을
(B)

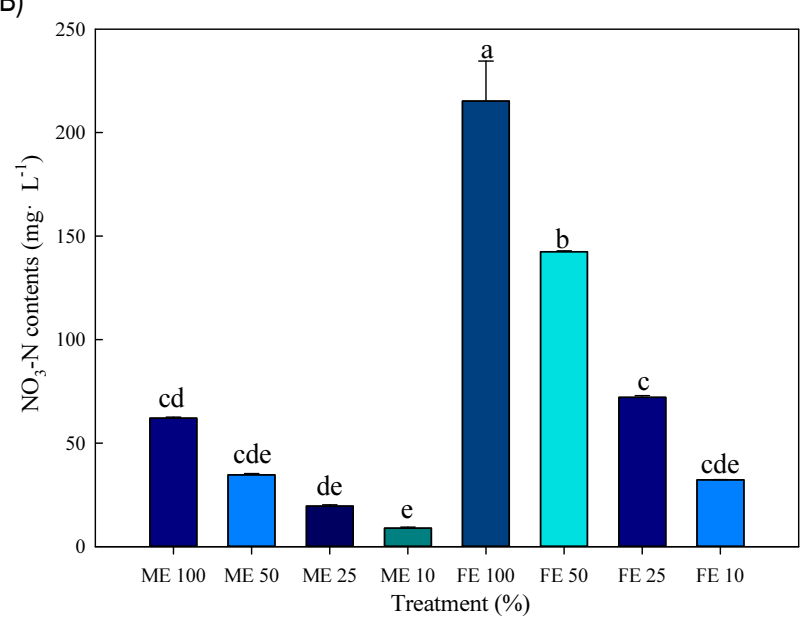

Fig. 3. Contents of Nitrogen in effluent waters (A: Ammonia nitrogen, B: Nitrate nitrogen). $\mathrm{FE}$, Fresh effluent water; ME, Matured effluent water.

100 , Effluent water; 50 , half strength of effluent water; 25 , quarter strength of Effluent water; 10 , tenth strength of Effluent water. 
통해 배출수에 있던 질산태 질소가 암모니아태 질소로 저장과정에 서 변환된 것이라 예상된다. 질산태 질소의 경우에는 배출수를 바 로 이용한 처리(FE)가 숙성시켜 이용한 처리(ME)에 비하여 확연 히 많은 량을 가지고 있었다(Fig. 3).

\subsection{2 배출수 내 기타 무기원소의 함량}

대체적으로 배출수를 바로 가져와 희석하지 않고 이용한 $\mathrm{FE}$ 100 처리구에서 대부분의 무기원소의 함량이 많이 측정되었다. 특 히 $\mathrm{Na}$ 의 함량이 FE 100 처리구에서 $631.5 \mathrm{mg} / \mathrm{L}$ 로 다른 무기원소 들의 함량에 비해 많은 량이 함유되어 있었다(Table 1). 고농도의 $\mathrm{Na}$ 이온은 근권의 삼투압을 증가시켜 수분과 양분의 흡수를 저해 하고 식물체내 독성 물질의 농도를 증가시키며 광합성과 호흡, 식
물 호르몬 조절능력 등의 생리적 장해와 체내 $\mathrm{Mg}$ 결핍을 초래한다 고 알려져 있으며(Munnus, 1993; Pasternak and Malach, 1995; Weimberg and Shannon, 1988), 또한 Seo et al.(2008)에 따르면 $\mathrm{Na}$ 가 토양에 집적되어 양이온 비율중 $\mathrm{Na}$ 함량이 $60 \%$ 이상일 경우 저온에서는 광합성율과 증산율을 감소시키고 생육 불량에도 영향 을 미친다고 하였다. 이에 따라 FE 100 처리구에서 고농도의 $\mathrm{Na}$ 이 온에 따른 생리적 장해 등이 발생하여 식물의 생장에 악영향을 미 칠 것으로 예상하였으나 실제 실험결과에서는 FE 100 처리가 상추 의 생육이 가장 뛰어났고(Table 2) 이 결과 BFT 양식장 배출수 원 액의 $\mathrm{Na}$ 농도는 식물 재배에 악영향으로 크게 작용하지 않을 것이 라고 판단된다.

Table 1. Content of ions in the effluent waters from Biofloc technology system of inland aquaculture.

\begin{tabular}{|c|c|c|c|c|c|c|c|c|}
\hline Treatment $^{\mathrm{z}}$ & $\mathrm{P}$ & $\mathrm{K}$ & $\mathrm{Ca}$ & $\mathrm{Mg}$ & $\mathrm{Na}$ & $\mathrm{Cl}$ & $\mathrm{HCO}_{3}$ & $\mathrm{SO}_{4}$ \\
\hline ME 100 & $4.5 \mathrm{~d}^{\mathrm{y}}$ & $47.2 \mathrm{~b}$ & $20.7 d$ & $6.1 \mathrm{~cd}$ & $361.4 \mathrm{~b}$ & $92.9 \mathrm{a}$ & $405.6 \mathrm{a}$ & $87.0 \mathrm{~b}$ \\
\hline ME 50 & $2.8 \mathrm{ef}$ & $23.4 \mathrm{c}$ & $21.4 d$ & $6.0 \mathrm{~cd}$ & $173.9 \mathrm{~cd}$ & $40.8 \mathrm{c}$ & $199.8 \mathrm{c}$ & $42.0 \mathrm{c}$ \\
\hline ME 10 & $1.1 \mathrm{~g}$ & $7.0 \mathrm{~d}$ & $16.2 d$ & $3.4 \mathrm{~d}$ & $43.3 \mathrm{e}$ & $17.2 \mathrm{~d}$ & $68.2 \mathrm{e}$ & $10.8 \mathrm{~d}$ \\
\hline FE 100 & $15.0 \mathrm{a}$ & $77.7 \mathrm{a}$ & $80.7 \mathrm{a}$ & $23.0 \mathrm{a}$ & $631.5 \mathrm{a}$ & $102.0 \mathrm{a}$ & $317.6 \mathrm{~b}$ & $137.3 \mathrm{a}$ \\
\hline FE 25 & $5.9 \mathrm{c}$ & $23.7 \mathrm{c}$ & $36.6 \mathrm{c}$ & $8.8 \mathrm{c}$ & $186.8 \mathrm{c}$ & $35.0 \mathrm{~cd}$ & $127.5 \mathrm{~d}$ & $43.8 \mathrm{c}$ \\
\hline FE 10 & $3.1 \mathrm{e}$ & $11.4 \mathrm{~d}$ & $24.2 d$ & $5.1 \mathrm{~d}$ & $85.1 \mathrm{e}$ & $20.2 d$ & $68.2 \mathrm{e}$ & $19.4 d$ \\
\hline
\end{tabular}

${ }^{\mathrm{z}} \mathrm{FE}$, Fresh effluent water; ME, Matured effluent water

100 , Effluent water; 50, half strength of effluent water; 25, quarter strength of Effluent water; 10, tenth strength of Effluent water.

${ }^{y}$ Mean separation within columns of each treatment by Duncan's multiple range test at $P=0.05$.

Table 2. Effect of the effluent waters from Biofloc technology system of inland aquaculture on the growth of lettuce.

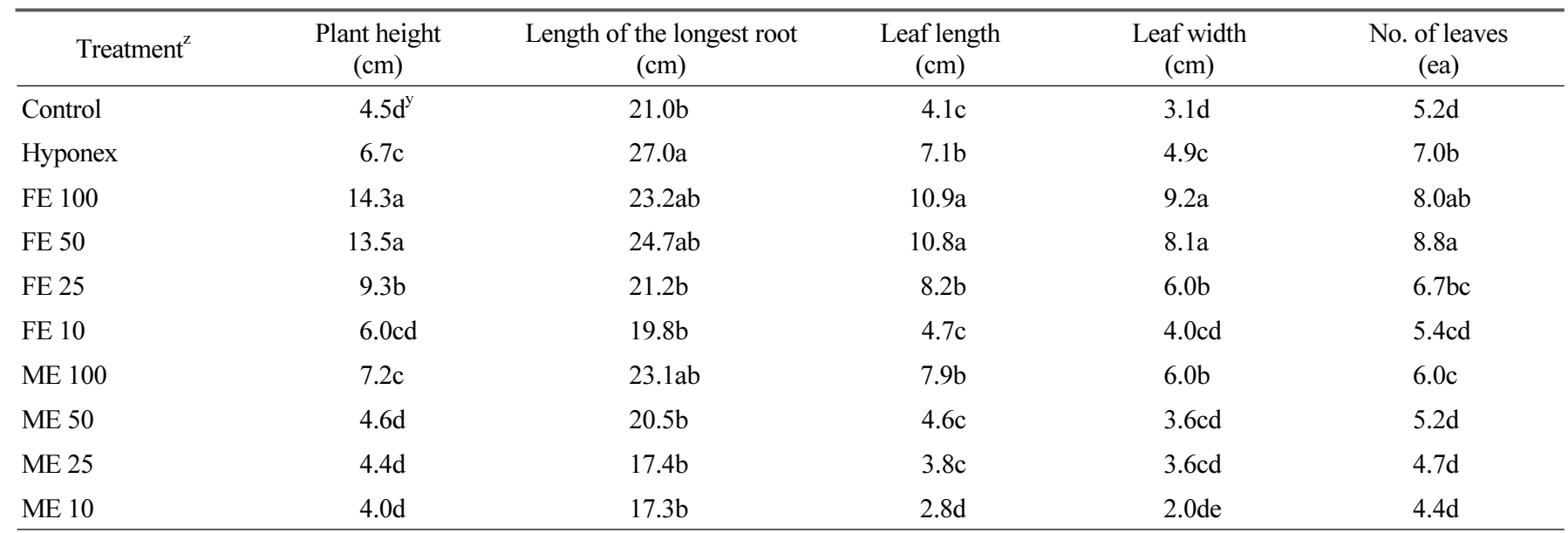

${ }^{\mathrm{z}} \mathrm{FE}$, Fresh effluent water; ME, Matured effluent water

100, Effluent water; 50, half strength of effluent water; 25, quarter strength of Effluent water; 10, tenth strength of Effluent water.

${ }^{y}$ Mean separation within columns of each treatment by Duncan's multiple range test at $P=0.05$. 
2. 상추의 생육에 미치는 영향

양식장 배출수를 이용하여 상추를 재배하는데 있어 일반 관행 액비와 함께 배출수의 사용방법 및 농도를 달리하여 6 주간 재배한 상추의 생육에 미치는 영향은 배출수를 가져와 숙성을 시키지 않고 바로 사용한 처리구(Fresh effluent water: FE 100, FE 50, FE 25, $\mathrm{FE} 10)$ 가 대체적으로 배출수를 가져와 상온 저장을 통해 숙성시킨 처리구(ME 100, ME 50, ME 25, ME 10)에 비하여 생육이 우수 하였다(Table 2). 특히 배출수를 가져와 바로 사용한 원액(FE 100) 처리구에서 다른 처리구에 비하여 생육이 월등하게 우수하였다. 이 에 반해 같은 원액을 사용하였지만 숙성을 시키지 않고 바로 이용 한 처리구 FE 100 처리구와 상온 저장을 통해 숙성을 시킨 ME 100 처리구는 생육에 큰 차이가 있었다. 그 이유로는 ME 100 처리구는 $\mathrm{pH}$ 7.9 9.3으로 높은 염기성을 띄고 있었으며, 고농도에서 식물에 생리적 장해를 일으키는 $\mathrm{NH}_{4}-\mathrm{N}$ 의 함량이 많아 이러한 결과를 나 타낸 것이라 생각된다. 이와 반대로 $\mathrm{FE} 100$ 처리구는 $\mathrm{pH}$ 7.3 7.6 정도로 상추 재배에 적절한 범위라고 알려진 $\mathrm{pH}$ 6.6 7.2와 근접하 며(Lee et al., 2013), $\mathrm{ME}$ 처리구와 달리 $\mathrm{NH}_{4}-\mathrm{N}$ 보다 고농도에서 도 크게 식물의 생리적 장해를 일으키지 않고 수용성이며 속효성이 나 토양입자에 잘 흡착하지 않아 물에 씻겨 내려가기 쉬워 밭작물 의 웃거름으로 쓰기에 유리하다고 알려진 $\mathrm{NO}_{3}-\mathrm{N}$ 의 함량이 많고 (Lim, 2006), $\mathrm{NH}_{4}-\mathrm{N}$ 을 제외한 다른 무기 원소들의 함량이 많았기 때문이라 생각된다. Ikeda and Osawa(1981)에 의하면 상추는 질 소원으로 이용에는 암모니아태 질소의 질소원을 선호한다고 하였 다. 이에 따라 본 실험의 결과로는 숙성시킨 배출수를 이용한 양액 에서 상추의 생육에서 긍정적인 영향을 미칠 것으로 예상하였으나
실험 결과에 따르면 숙성시키지 않은 배출수를 이용한 $\mathrm{FE}$ 처리에 서 생육이 뛰어 났다. 이러한 이유로는 ME처리에 암모니아태 질소 함량이 많기는 하지만 전체적인 질소원의 함량으로 보면 $\mathrm{FE}$ 처리 가 월등히 많았기 때문에 $\mathrm{ME}$ 처리에 있는 암모니아태 질소는 상추 의 생육에 큰 영향을 미치지 못한 것으로 판단된다. 또한 관행 액비 를 사용한 처리와 비교해보면 배출수를 가져와 바로 이용한 처리인 $\mathrm{FE} 100$ 처리구와 FE 50 처리구에서 생육이 뛰어난 것을 알 수 있 었다.

또한 배출수를 바로 이용한 처리인 $\mathrm{FE}$ 처리구에서도 농도에 따 라 생육의 차이가 크게 나타났는데 배출수를 원액으로 이용한 처리 (FE100)와 배출수를 $1 / 2$ 배 농도로 희석하여 이용한 처리(FE50)

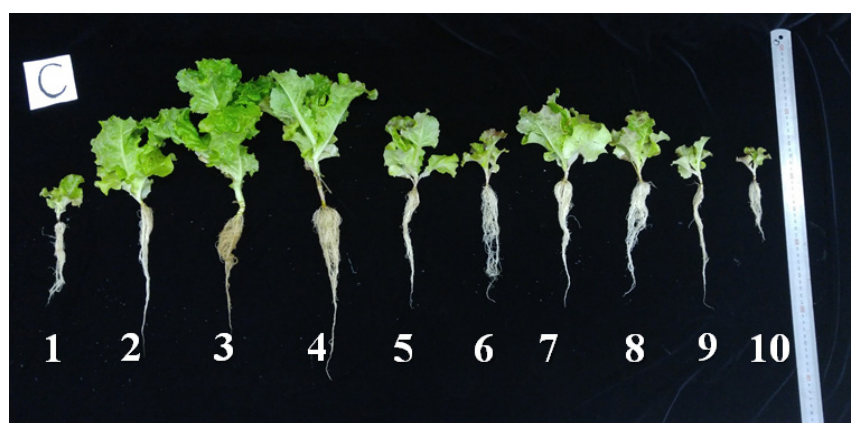

Fig. 4. Effect of the effluent waters from Biofloc technology system of inland aquaculture on the growth of lettuce (1: Control, 2: Hyponex, 3: FE100, 4: FE50, 5: FE25, 6: FE10, 7: ME100, 8: ME50, 9: ME25, 10: ME10). $F E$, Fresh effluent water; $M E$, Matured effluent water. 100 , Effluent water; 50 , half strength of effluent water; 25 , quarter strength of Effluent water; 10, tenth strength of Effluent water.

Table 3. Effect of the effluent waters from Biofloc technology system of inland aquaculture on the growth of lettuce.

\begin{tabular}{|c|c|c|c|c|c|c|}
\hline \multirow{2}{*}{ Treatment $^{\mathrm{z}}$} & \multirow{2}{*}{$\begin{array}{l}\text { Chloropyll content } \\
\text { (SPAD) }\end{array}$} & \multirow{2}{*}{$\begin{array}{l}\text { Stem diameter } \\
(\mathrm{mm})\end{array}$} & \multicolumn{2}{|c|}{ Fresh weight (g) } & \multicolumn{2}{|c|}{ Dry weight (g) } \\
\hline & & & Shoot & Root & Shoot & Root \\
\hline Control & $15.7 \mathrm{ab}^{\mathrm{y}}$ & $2.7 \mathrm{~d}$ & $1.3 \mathrm{~d}$ & $1.0 \mathrm{~d}$ & $0.1 \mathrm{~d}$ & $0.1 \mathrm{de}$ \\
\hline Hyponex & $14.3 \mathrm{bc}$ & $4.0 \mathrm{c}$ & $4.9 \mathrm{c}$ & $2.8 \mathrm{c}$ & $0.3 \mathrm{c}$ & $0.2 \mathrm{c}$ \\
\hline FE 100 & $16.7 \mathrm{a}$ & $7.4 \mathrm{a}$ & $16.4 \mathrm{a}$ & $8.0 \mathrm{a}$ & $1.1 \mathrm{a}$ & $0.5 \mathrm{a}$ \\
\hline FE 50 & $14.1 b c$ & $5.7 \mathrm{~b}$ & $13.7 \mathrm{~b}$ & $6.6 b$ & $0.9 \mathrm{~b}$ & $0.4 \mathrm{~b}$ \\
\hline FE 25 & $12.3 \mathrm{~cd}$ & $4.2 \mathrm{c}$ & $5.9 \mathrm{c}$ & $3.2 \mathrm{c}$ & $0.5 \mathrm{c}$ & $0.3 \mathrm{c}$ \\
\hline FE 10 & $10.5 \mathrm{~d}$ & $3.1 \mathrm{~d}$ & $1.6 \mathrm{~d}$ & $1.4 \mathrm{~d}$ & $0.2 \mathrm{~d}$ & $0.1 \mathrm{~d}$ \\
\hline ME 100 & $12.7 \mathrm{~cd}$ & $4.1 \mathrm{c}$ & $4.3 \mathrm{c}$ & $3.1 \mathrm{c}$ & $0.4 \mathrm{c}$ & $0.2 \mathrm{c}$ \\
\hline ME 50 & $11.2 \mathrm{~d}$ & $3.2 \mathrm{~d}$ & $1.6 \mathrm{~d}$ & $1.6 \mathrm{~d}$ & $0.2 \mathrm{~d}$ & $0.1 \mathrm{~d}$ \\
\hline ME 25 & $9.3 \mathrm{e}$ & $2.6 \mathrm{ef}$ & $1.0 \mathrm{de}$ & $0.9 \mathrm{ef}$ & $0.1 \mathrm{~d}$ & $0.1 \mathrm{de}$ \\
\hline ME 10 & $7.5 \mathrm{ef}$ & $2.1 \mathrm{f}$ & $0.4 \mathrm{e}$ & $0.4 \mathrm{f}$ & $0.1 \mathrm{~d}$ & $0.1 \mathrm{e}$ \\
\hline
\end{tabular}

${ }^{\mathrm{z}} \mathrm{FE}$, Fresh effluent water; ME, Matured effluent water

100 , Effluent water; 50, half strength of effluent water; 25, quarter strength of Effluent water; 10, tenth strength of Effluent water.

${ }^{\mathrm{y}}$ Mean separation within columns of each treatment by Duncan's multiple range test at $P=0.05$. 
에서는 상추의 생육에 비료로서 시용효과가 뛰어났는데, 시용농도 를 1/4배(FE25), 1/10배(FE10)로 하게 되면 배출수의 비료효과는 급격하게 떨어지는 것을 알 수 있었다(Table 2, 3, Fig. 4). 이러한 결과에 따라 양식장 배출수를 비료화하기 위해서는 배출수를 가져 와 희석시키지 않고 바로 사용하는 것이 효과적이라는 것을 알 수 있었다.

\section{IV. 적요}

내수면 양식장의 규모가 갈수록 커져가고 이에 따라 많은 연구 가 진행되고 있는 현재 양식장에서 배출되는 슬러지와 배출수는 최 근 수질오염원으로 부각되어 배출에 제한이 심해지고 있는 상황이 다. 본 연구에서는 양식장에서 배출되는 유출수의 처리문제를 해결 하기 위해 실시하였다. 양식장에서 배출되는 슬러지와 배출수에는 식물의 생장에 필요한 여러 가지 무기 원소와 이온들이 풍부하여 식물의 재배에 이용되는 화학비료를 대체하기에 효율적이라고 사 료되어 이를 이용한 식물 비료로의 사용 방법에 대하여 실험을 진 행하였다. 실험의 결과 배출수를 식물 비료로 이용하기 위해서는 배출수를 채취하여 숙성시키지 않고 원액을 그대로 이용하는 것이 가장 효율적이라는 것을 알 수 있었다. 그러나 배출수를 농업적으 로 이용하기 위해 상업용 비료를 만들기에는 어려운 점이 있기에 이용상 접근이 용이한 도시농업의 유기농 비료 대책으로써 활용하 는 것이 적합하다고 판단된다. 이처럼 도시농업적 활용을 위하여 추가적으로 배출수의 이용 따른 세균 등의 재배 작물 유해 가능 요 인에 대한 검토가 필요하며, 또한 본 실험에서의 연구결과를 바탕 으로 실질적인 도시농업 재배방법에 적용 가능한 배출수의 이용방 법 및 배출수 내 고농도의 $\mathrm{Na}$ 이온을 조절하는 방안이 개발되어야 할 것이다.

\section{References}

Buckling, R.A., C.D. Baird, C.A. Watson, and F.A. Chapman. 1993. Energy use of recycling water aquaculture systems for ornamental fish production. Circular 1095. Florida Cooperative Extension Service. Institute of Food and Agricultural Sciences, Univ. of Florida, Gainesville, FL, 5 pp.

Cho, J.C., S.H. Lee., S.J. Park, and S.J. Kim. 1995. Environmental impacts of inland based trout-farms on the water quality of a stream. Kor. J. Sanitation 10(3):56-66.

Jo, S.H., T.H. Park, and K.W. Chang. 2001. Effects of Brassiea campestris L. and Lactuca sativa L. yield by application of organic fertilizers and microorganisms. J. Kor. Organic Resource Recycling Assoc. 9(3):88-92.

Kang, C.S., A.S. Roh, S.K. Kim, and K.Y. Park. 2011. Effects of the application of livestock mannure compost on reducing the chemical fertilizer use for the lettuce cultivation in green house. Korean J. Soil Sci. Fertil. 44(3):457-464.

Kim, H.J., J.H. Ryu, M.S. Park, and D.Y. Chung. 2011. Underappreciated resource phosphorus: implications in agronomy. Korean J. Soil Sci. Fertil. 44(1):78-83.

Kim, W.B., Y.G. Kwon, S.W. Jang, and S.C. Lim. 2001. Effect of application on the growth of head lettuce under fertigation conditions in highland. Korean J. Plant Resour. 14(1):84-88.

Lim, S.U. 2006. Fertilizer. 1st ed. Ilshin Press, Incheon, Korea.

Munnus, R. 1993. Physiological processes limiting plant growth in saline soil: some dogmas and hypotheses. Plant Cell Environ. 16:15-24.

Park, C.K., Y.S. Lee, K.R. Cho, S.Y. Won, and Y.J. Choi. 2001. Effects of matuation periods of pig manure composts on growth of leaf lettuce (Lactuca sativa L.). Korea J. Org. Agric. 9(1):19-29.

Pasternak, D. and Y. DeMalach. 1995. Crop irrigation with salinewater. In: Pessarakli, M. (Ed), Handbook of plant and crop stress. Marcel Dekker, Inc., NY. pp.599-622.

Ryoo, J.W. 2011. The nutrients and microbial properties of animal manure and spent mushroom compost tea and the effect of growth of lettuce (Lactuca sativa L.). Korea J. Org. Agric. 19(4):589-602.

Ryu, H.I., J.G. Ryu, O.S. Kwon, Y.J. Lee, S.H. Lee, K.I. Kang, and E.K. Park. 1993. Studies on the treatment and disposal of pollutants from fish farming effluents (I). National Institute of Environmental Research. pp.9-12. Incheon, Korea.

Seo, I.S., P.K. Shin, S.D. Lee, and M.J. Chung. 1997. The studies on the biological treatment of fish-excretion. Korean J. Chem. Eng. Res. 3(1):761-765.

Seo, Y.J., J.S. Kim, C.Y. Kim, S.D. Park, and M. Park. 2008. Effect of sodium in artificial substrate on the growth, gas exchange and leaf water status of cucumber (Cucumis sativa L.) and Korea melon (Cucumis melo L.). Korean J. Soil Sci. Fertil. 41(3):177-183.

Shin, B.K., J.E. Son, and J.M. Choi. 2013. Impact of compositions and concentrations of fertilizer solution on growth of lettuce and changes in chemical properties of root media. Protected Hort. Plant Fac. 22(3):193-201.

Subramanianm, S., S.A. Mahali, and S.H.M. Taha. 1994. Red tide phenomena in Brunei Darussalam - some implications for fisheries. Hydrobiologia 28:219-225.

Weimberg, R. and M.C. Shannon. 1988. Vigor and salt tolerance in 3 lines of tall wheat grass. Physiol. Plant 73:232-237. 